\title{
Oncostatic effects of the indole melatonin and expression of its cytosolic and nuclear receptors in cultured human melanoma cell lines
}

\author{
T.W. FISCHER ${ }^{1,3}$, M.A. ZMIJEWSKI ${ }^{1}$, B. ZBYTEK ${ }^{1}$, T.W. SWEATMAN ${ }^{2}$, \\ R.M. SLOMINSKI ${ }^{1}$, J. WORTSMAN ${ }^{4}$ and A. SLOMINSKI ${ }^{1}$
}

\begin{abstract}
Departments of ${ }^{1}$ Pathology and Laboratory Medicine and ${ }^{2}$ Pharmacology, University of Tennessee Health Science Center, Memphis, TN, USA; ${ }^{3}$ Department of Dermatology, University Hospital Schleswig-Holstein, University of Lübeck, Lübeck, Germany; ${ }^{4}$ Department of Internal Medicine, Southern Illinois University, Springfield, IL, USA
\end{abstract}

Received March 13, 2006; Accepted May 11, 2006

\begin{abstract}
Melatonin has been shown to have oncostatic effects on malignant melanoma in vitro and in vivo. We studied the growth suppressive effects of melatonin over a wide range of concentrations in four melanoma cell lines (SBCE2, WM-98, WM-164 and SKMEL-188) representative for different growth stages and phenotype. Melanoma cells were incubated with melatonin $10^{-12}-10^{-3} \mathrm{M}$, and proliferation and clonogenicity was assessed at $12 \mathrm{~h}$ and 14 days, respectively. We also determined the expression of cytosolic quinone oxidoreductases NQO1, NQO2 (known as MT3 receptor) and nuclear receptor ROR $\alpha$ by RT-PCR. Melatonin at pharmacological concentrations $\left(10^{-3}-10^{-7} \mathrm{M}\right)$ suppressed proliferation in all melanoma cell lines. In SKMEL-188 cells cultured in serum-free media, melatonin at low concentrations $\left(10^{-12}\right.$ $10^{-10} \mathrm{M}$ ) also slightly attenuated the proliferation. The effects of pharmacological doses of melatonin were confirmed in the clonogenic assay. Expression of NQO1 was detected in all cell lines, whereas NQO2 and nuclear receptor ROR $\alpha$ including its isoform ROR $\alpha 4$ were present only in SBCE2, WM-164 and WM-98. Thus, melatonin differentially suppressed proliferation in melanoma cell lines of different behaviour. The intensity of the oncostatic response to melatonin could be related to the cell-line specific pattern of melatonin cellular receptors and cytosolic binding protein expression.
\end{abstract}

\section{Introduction}

Melatonin acts as a hormone $(1,2)$, receptor independent autocrine and paracrine antioxidant $(3,4)$, direct radical scavenger

Correspondence to: Dr Andrzej Slominski, Department of Pathology and Laboratory Medicine, University of Tennessee Health Science Center, 930 Madison Avenue, Memphis, TN 38163, USA

E-mail: aslominski@utmem.edu

Key words: melanoma, ROR/RZR receptor, quinone oxidoreductase, cytosolic receptor, melatonin
$(3,5)$, immunomodulator $(6)$, antiaging factor $(7,8)$ and anticarcinogen (9) depending on the concentrations (10). Increasing evidence in the field suggests that melatonin acts at many extrapineal sites such as the gastrointestinal tract $(11,12)$, the blood cell system (13), the retina (14), the bone marrow $(15,16)$ and the skin $(17-22)$. In the epidermal keratinocytes, a constitutive and UV-induced melatonin metabolism has recently been described (23). Under physiologic conditions, melatonin participates in the regulation of keratinocyte proliferation (24-26), hair growth (26-31) and melanogenesis $(32,33)$. In conditions of oxidative stress, it acts as an antioxidant (18,34-36) and UV-protective substance $(18,22,37,38)$. These actions may result in protective, proliferative and antiapoptotic effects to ensure the survival of non-neoplastic cells.

In contrast, in malignant processes, melatonin has been shown to inhibit tumor growth by decreasing cell growth through proapoptotic actions. These effects had been observed in tumor cell lines of breast (39), prostate (40) and colon carcinoma (41). Melanoma is an aggressive form of skin cancer associated with high mortality and limited response to therapy once extended beyond the skin (42-44). Melatonin has been shown to suppress cell growth in selected cutaneous and uveal melanoma cell lines of rodent and human origin (32,45-47). Also clinically, there is some evidence for melatonin having potent antineoplastic activity (48-51). The biological activity of melatonin is enhanced by its strong lipophilic property that allows for easy penetration through cell membranes and the possibility of direct intracellular actions. The anticarcinogenic effect seems to be increased through membrane, cytosolic and/or nuclear receptors $(45,47,52,53)$. The membrane receptors, represented by MT1 and MT2, belong to a G-protein coupled receptor super-family which can bind to a variety of G-proteins (54-56) and are differentially expressed in melanoma cell lines (24). Cytosolic NRH:quinone oxidoreductase 2 (NQO2, QR2) possesses melatonin binding sites previously described as MT3 receptor (57), differing in this aspect from NAD(P)H:quinone oxidoreductase 1 (NQO1, QR1) (58). Melatonin nuclear receptors, recently identified in keratinocytes, melanocytes and fibroblasts (18) as well as in hair follicles (28), belong to the retinoid orphan receptor subfamily (RZR/ROR). It was shown that all these human 
Table I. Sequences of primers used for RT-PCR amplifications.

\begin{tabular}{llcr}
\hline Gene & \multicolumn{1}{c}{ Primer } & Fragment size (bp) & Ref. \\
\hline ROR $\alpha$ common fragment & MZ013 5'-GCTGACATCAGTACAAATGCAG-3' & 320 & 76 \\
& MZ014 5'-GGAAGAGCTCCAGCAGATAACG-3' & & 59 \\
ROR $\alpha$ 1 forward & MZ016 5'-AAACATGGAGTCAGCTCCG-3' & 475 & 59 \\
ROR $\alpha$ f forward & MZ017 5'-CTCCAAATACTCCATCAGTGTATCC-3' & 414 & 59 \\
ROR $\alpha 3$ forward & MZ018 5'-CAACTTGAGCACATAAACTGG-3' & 369 & 59 \\
ROR $\alpha$ 4/RZR $\alpha$ & MZ015 5'-CGCACCGCGCTTAAATGATG-3' & 416 & 59 \\
Common reverse primer & MZ019 5'-CATACAAGCTGTCTCTCTGC-3' & & 73 \\
for ROR-1-4 & MZ020 5'-GAGGACCTCCTTCAACTATGCC-3' & 365 & 73 \\
NQO1 & MZ021 5'-CCTTTGTCATACATGGCAGCG-3' & & \\
& MZ022 5'-GGAACCCAAGTCTTTCAACGG-3' & 622 & \\
NQO2 & MZ023 5'-TGGGCTCTTCCTTCCAGATGG-3' & & \\
&
\end{tabular}

nuclear receptors are splicing variants $[R O R \alpha 1, R O R \alpha 2$, $\mathrm{ROR} \alpha 3, \mathrm{ROR} \alpha 4$ (also named $\mathrm{RZR} \alpha$ )] of the ROR $\alpha$ gene $(18,40,59)$.

Here, we tested melatonin for its potential oncostatic effects by assaying for proliferation and colony growth suppression in four different melanoma cell lines (three amelanotic lines including SBCE2, WM-98 and WM-164 derived from vertical and radial growth phases or metastasis, respectively, and SKMEL-188, which can produce melanin pigment). We also analysed the expression of quinone oxidoreductase 1 and 2 as well as $\mathrm{ROR} \alpha$ nuclear receptor and its isoforms $\operatorname{ROR} \alpha 1$, $\mathrm{ROR} \alpha 2, \mathrm{ROR} \alpha 3$ and $\mathrm{ROR} \alpha 4$.

\section{Materials and methods}

Cell culture, melatonin treatment and $\left[{ }^{3} \mathrm{H}\right]$-thymidine incorporation. The human melanoma lines used consisted of SKMEL-188, WM-164, WM-98 and SBCE2. The human hypomelanotic melanoma cell line SKMEL-188 [inducible to differentiate by high concentration of tyrosine (60)] was cultured in Ham's F-10 medium with L-glutamine (Cellgro Mediatech Inc., Herndon, VA). The human amelanotic melanoma lines, established from radial growth phase (SBCE2), vertical growth phase (WM-98) and metastasis (WM-164) (gift of M. Herlyn, Wistar Institute, Philadelphia, PA) were grown in Dulbecco's modified Eagle's medium (DMEM) supplemented with glucose, L-glutamine and pyridoxine hydrochloride (Gibco, Rockville, MD). According to standard protocols, the media contained 5\% horse-serum (Invitrogen Corp., Carlsbad, CA), antibiotics (Gibco) and insulin (5 $\mu \mathrm{g} / \mathrm{ml}$; Sigma Chemical Co., St. Louis, MO) in the presence of $5 \%$ $\mathrm{CO}_{2}$ (61). The culture media were changed every other day.

For experiments, melatonin (Sigma) was dissolved in ethanol and further diluted to corresponding test concentrations with PBS (final ethanol concentration $<0.2 \%$ ). The test cells were removed from culture flasks by trypsinization and seeded at a density of $10^{3}$ cells/well in a 96-well microtiter plate (Corning Inc., Corning, NY). Cells were used for experiments after overnight adherence, reaching 70-80\% confluency. Before starting melatonin treatment, two different culture conditions were chosen: i) supplemented media were replaced by serumfree media for $24 \mathrm{~h}$ to achieve cell cycle synchronisation, and ii) the supplemented media were maintained for $24 \mathrm{~h}$ by adding fresh media containing horse-serum. Cells were then incubated with melatonin at graded concentrations from $10^{-12}$ to $10^{-3} \mathrm{M}$ in fresh media $+/$ - horse-serum corresponding to pretreatment regimen. Parallel controls were incubated with the same media, but without melatonin. After $12 \mathrm{~h}$, melatonin was added again at the same concentrations together with $\left[{ }^{3} \mathrm{H}\right]$-thymidine, $1 \mu \mathrm{Ci} / \mathrm{ml}$ medium (Amersham Biosciences, Picataway, NY; specific activity $88.0 \mathrm{Ci} / \mathrm{mmol}$ ). Media containing melatonin and $\left[{ }^{3} \mathrm{H}\right]$-thymidine were discarded $12 \mathrm{~h}$ later, cells were detached with trypsin and harvested on a glass fiber filter (Packard, Meriden, CA). ${ }^{3} \mathrm{H}$-radioactivity incorporated in DNA as a marker for cell proliferation was measured with a beta counter (Direct Beta-Counter Matrix 9600, Packard, Meriden, CA).

Colony-forming assay. The SKMEL-188 and SBCE2 melanoma cells were selected for the colony-forming assay. Cells were seeded in Petri dishes at a density of 65 cells $/ \mathrm{cm}^{2}$ and allowed to adhere during overnight incubation at $37^{\circ} \mathrm{C}$ and $5 \% \mathrm{CO}_{2}$. Cells were then further incubated with fresh media supplemented with horse-serum $(5 \%)$ containing melatonin at concentrations of $10^{-11}, 10^{-6}, 10^{-4}$ and $10^{-3} \mathrm{M}$ for SKMEL-188 melanoma cells and $10^{-12}, 10^{-10}, 10^{-6}, 10^{-4}$ and $10^{-3} \mathrm{M}$ for SBCE2 melanomas. Cells were cultured for 14 days at $37^{\circ} \mathrm{C}$ and $5 \% \mathrm{CO}_{2}$ to allow for colony formation, and media containing melatonin at the test concentrations were changed every $72 \mathrm{~h}$. After 14 days, colonies were fixed with $4 \%$ paraformaldehyde overnight at $4^{\circ} \mathrm{C}$, stained with crystalline blue and counted with a colony counter (ARTEK counter, Model 880, DYNEX Technologies Inc., Chantilly, VA).

cDNA preparation and $R T-P C R$. Total RNA was prepared with a total RNA extraction kit (Qiagen, Valencia, CA) 
A.

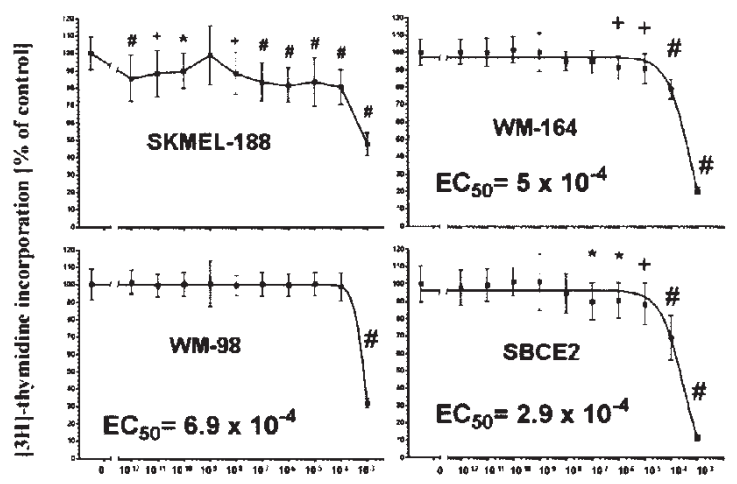

melatonin concentration [M]

B.

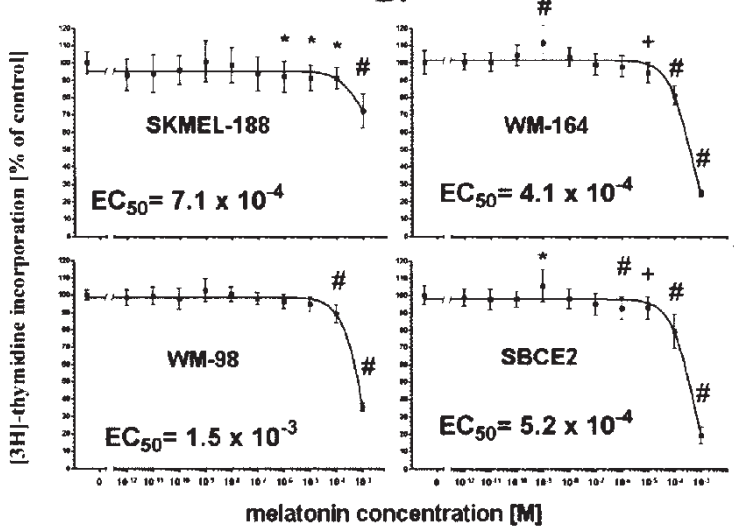

Figure 1. Inhibition of melanoma cell proliferation by melatonin. A, serumfree condition. Melatonin at the concentration of $10^{-3}-10^{-8} \mathrm{M}$ and $10^{-10}-10^{-12} \mathrm{M}$ significantly suppressed $\left[{ }^{3} \mathrm{H}\right]$-thymidine incorporation into SKMEL-188 melanoma cells under a starving condition (SKMEL-188). WM-164 melanoma cells were inhibited by melatonin at the concentrations of $10^{-3}$ $10^{-6} \mathrm{M}$ (WM-164). In WM-98 melanoma cells, suppression was only significant at the melatonin concentration of $10^{-3} \mathrm{M}$ (WM-98). SBCE2 melanoma cells were significantly suppressed at the melatonin concentration of $10^{-3}-10^{-7} \mathrm{M}$ (SBCE2). ${ }^{*} \mathrm{p}<0.05 ;{ }^{+} \mathrm{p}<0.01 ;{ }^{*} \mathrm{p}<0.001$; mean \pm SD. B, serumsupplemented condition. Cell growth in SKMEL-188 was significantly suppressed by melatonin concentrations of $10^{-3}-10^{-6} \mathrm{M}$ (SKMEL-188). In WM-164 melanoma cells, inhibition of proliferation was exerted by melatonin concentrations of $10^{-3}-10^{-5} \mathrm{M}$ (WM-164). WM-98 cells were only significantly suppressed by the concentration of $10^{-3}-10^{-4} \mathrm{M}$ (WM-98), and SBCE2 melanoma cells showed suppression by melatonin at concentrations between $10^{-3}$ and $10^{-6} \mathrm{M}$ (SBCE2). A slight proliferative effect by melatonin was observed at the concentration of $10^{-9} \mathrm{M}$ in WM-164 and SBC2 melanoma cells. ${ }^{*} \mathrm{p}<0.05 ;{ }^{+} \mathrm{p}<0.01 ;{ }^{*} \mathrm{p}<0.001 ;$ mean $\pm \mathrm{SD}$.

supplemented with an RNase-free DNase set (Qiagen, Valencia, CA). Two $\mu \mathrm{g}$ of total RNA was reverse transcribed with a SuperScript first-strand synthesis system (Applied Biosystems, Foster City, CA). Quality and quantity of all samples were standardized through amplification of the housekeeping gene glyceraldehyde-3-phosphate dehydrogenase (GAPDH) and 18S rRNA subunit as described previously (18). Primers used for PCR amplification were synthesized by Integrated DNA (Technology Inc., Coralville, IA) and are listed in Table I. PCR reactions were carried out as described previously, using PCR Master Mix (Promega) and $0.4 \mathrm{mM}$ of each primer. Amplification products were separated by agarose gel electrophoresis, visualized by ethidium bromide staining and analyzed with QuantityOne software (Bio-Rad Laboratories, Hercules, CA).
Table II. Inhibition of proliferation in melanoma cell lines exposed to melatonin at the concentration of $10^{-3} \mathrm{M}^{\mathrm{a}}$

Cell line

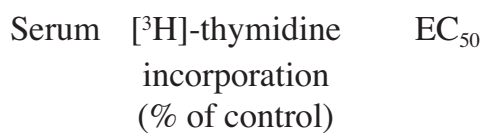

\begin{tabular}{lccc}
\hline $\begin{array}{l}\text { SKMEL-188 } \\
\text { (hypomelanotic }\end{array}$ & - & $\sim 50$ & - \\
$\begin{array}{l}\text { phenotype) } \\
\text { WM-164 }\end{array}$ & + & $\sim 70$ & $7.1 \times 10^{-4} \mathrm{M}$ \\
$\begin{array}{l}\text { (metastatic stage) } \\
\text { WM-98 }\end{array}$ & + & $\sim 20$ & $5.0 \times 10^{-4} \mathrm{M}$ \\
$\begin{array}{l}\text { (vertical growth phase) } \\
\text { SBCE2 }\end{array}$ & + & $\sim 25$ & $4.1 \times 10^{-4} \mathrm{M}$ \\
(radial growth phase) & + & $\sim 30$ & $6.9 \times 10^{-4} \mathrm{M}$ \\
& - & $\sim 10$ & $1.5 \times 10^{-3} \mathrm{M}$ \\
\hline
\end{tabular}

aThe inhibitory effect of melatonin is more pronounced under a serum-free condition (synchronized) compared to a serumsupplemented condition.

Statistical analysis. $\left[{ }^{3} \mathrm{H}\right]$-thymidine incorporation into DNA was measured separately for each well and the results from 12 wells per condition were calculated as the mean in a series of repeated independent experiments. Data were analysed with GraphPad Prism Version 4.0 (GraphPad Software Inc., San Diego, CA) using One-way-ANOVA with appropriate post hoc testing. Differences were considered significant when $\mathrm{p}<0.05$. Numbers of colonies were calculated as the mean of three measurements per condition and analysed as above.

\section{Results}

Proliferation assay. A distinct inhibitory effect on melanoma cell proliferation by melatonin was observed in all cell lines. The effect was more pronounced in synchronized cell-cycle growth [serum-free condition (Fig. 1A)] than in cells growing under serum-supplemented conditions (Fig. 1B). The concentration of $10^{-3} \mathrm{M}$ melatonin showed the strongest suppression in all cell lines $(\mathrm{p}<0.001)$, however, the magnitude of the effect differed across cell lines (Table II and Fig. 1). In SKMEL-188 melanoma cells, melatonin at the concentration of $10^{-3} \mathrm{M}$ suppressed proliferation to $50 \%$ of control in a serum-free condition, and to $70 \%$ in a serum-supplemented condition. The $\mathrm{EC}_{50}$ in the serum-supplemented condition was $7.1 \times 10^{-4} \mathrm{M}$. In the serum-free condition a biphasic dose response was observed (Fig. 1A; SKMEL-188 panel). By comparison, in the WM-164 melanoma cell line (of metastatic origin), melatonin at a pharmacological concentration led to a suppressed viability of $20 \%$ (serum-free) and $25 \%$ (supplemented) of untreated control. The $\mathrm{EC}_{50}$ was 5 and $4.1 \times 10^{-4} \mathrm{M}$, respectively. In WM-98 melanoma cells (vertical growth phase), melatonin at $10^{-3} \mathrm{M}$ showed reduced proliferation of $30 \%$ (serum-free) and $35 \%$ (supplemented) of 
Table III. Melatonin-induced suppression of proliferation in melanoma cell lines over a wide range of concentrations.

\begin{tabular}{|c|c|c|c|c|c|c|c|c|c|c|c|}
\hline \multirow[b]{2}{*}{ Cell line } & \multirow[b]{2}{*}{ HS supplement } & \multicolumn{10}{|c|}{ Melatonin concentration (M) } \\
\hline & & $10^{-12}$ & $10^{-11}$ & $10^{-10}$ & $10^{-9}$ & $10^{-8}$ & $10^{-7}$ & $10^{-6}$ & $10^{-5}$ & $10^{-4}$ & $10^{-3}$ \\
\hline \multirow[t]{2}{*}{ SKMEL-188 } & No & +++ & ++ & + & - & ++ & +++ & +++ & +++ & +++ & +++ \\
\hline & Yes & - & - & - & - & - & - & + & + & + & +++ \\
\hline \multirow[t]{2}{*}{ WM-164 } & No & - & - & - & - & - & - & ++ & ++ & +++ & +++ \\
\hline & Yes & - & - & - & IP & - & - & - & ++ & +++ & +++ \\
\hline \multirow[t]{2}{*}{ WM-98 } & No & - & - & - & - & - & - & - & - & - & +++ \\
\hline & Yes & - & - & - & - & - & - & - & - & +++ & +++ \\
\hline \multirow[t]{2}{*}{ SBCE2 } & No & - & - & - & - & - & + & + & ++ & +++ & +++ \\
\hline & Yes & - & - & - & IP & - & - & +++ & ++ & +++ & +++ \\
\hline
\end{tabular}

HS, horse-serum. +, suppression of proliferation; level of significance $\mathrm{p}<0.05$. ++ , suppression of proliferation; level of significance $\mathrm{p}<0.01$. +++ , suppression of proliferation; level of significance $\mathrm{p}<0.001$. -, no effect on proliferation. IP, increased proliferation $(\mathrm{p}<0.001)$.

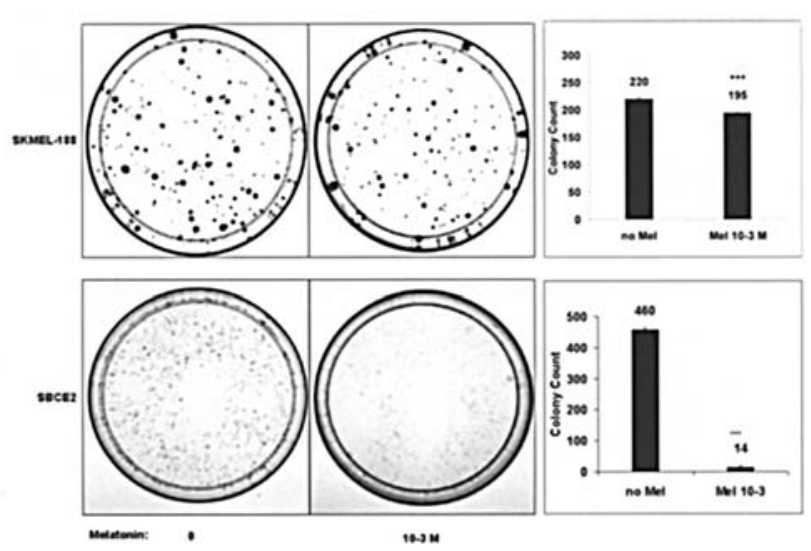

Figure 2. Effect of melatonin on colony forming ability by SKMEL-188 and SBCE2 melanomas. Melatonin at the concentration of $10^{-3} \mathrm{M}$ led to significant suppression of colony formation. Colony counts in SKMEL-188 melanoma cells (upper panel) decreased to $89 \%$ of controls; in SBCE2melanoma cells, suppression was down to $3 \%$ of control (lower panel). Experiments were performed in duplicate or triplicate. ${ }^{* * *} \mathrm{p}<0.001$.

control and an $\mathrm{EC}_{50}$ of $6.9 \times 10^{-4}$ and $1.5 \times 10^{-3} \mathrm{M}$. The strongest suppression was observed in the SBCE2 melanoma cell line (derived from radial growth phase) with only 10 and $20 \%$ cell survival compared to control. The $\mathrm{EC}_{50}$ was 2.9 and $5.2 \times 10^{-4} \mathrm{M}$. The sensitivity to melatonin over a wide range of treatment concentrations was however dissociated from the effect on proliferation suppression. Thus, the SKMEL-188 cell line showed significant suppression at both high $\left(10^{-3}-10^{-8} \mathrm{M}\right)$ and low $\left(10^{-10}-10^{-12} \mathrm{M}\right)$ melatonin concentrations (Fig. 1A). The suppressive effect of low melatonin concentrations was not seen in the other cell lines (Fig. 1). Surprisingly, two cell lines (WM-164 and SBCE2) showed a slight increase of proliferation after incubation with melatonin at the concentration of $10^{-9} \mathrm{M}$ in serum-supplemented condition (Fig. 1B). An overview of these results is presented in Table III.

Colony-forming assay. The cell lines SKMEL-188 and SBCE2 were used for the clonogenic growth assay. Melatonin at

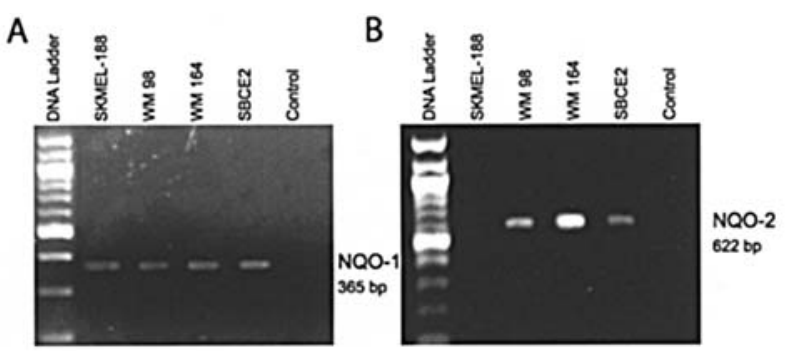

Figure 3. Expression of NQO1 and NQO2 in human melanoma cell lines. NQO1 is present in all tested cell lines; NQO2 was identified in WM-164 > WM-98 > SBCE2 (from highest to lowest expression). Characteristic fragments of NQO1 (A), and NQO2 (B) mRNA were amplified by RT-PCR (73). Last line in each panel represents negative control without cDNA.

the concentration of $10^{-3} \mathrm{M}$ suppressed colony formation significantly, but again there was a difference in the magnitude of the effect between the two cell lines. While the colony number in melatonin-treated SKMEL-188 melanoma cells showed an $11.4 \%$ reduction compared to controls $(\mathrm{p}<0.001$; Fig. 2, upper panel), in the SBCE2 melanoma cell line the reduction was $97 \%$ ( $p<0.001$; Fig. 2, lower panel). Moreover and in correspondence with the thymidine incorporation assay, SKMEL-188 melanoma cells showed significant suppression by melatonin at lower concentrations $\left(10^{-6}\right.$ and $\left.10^{-11} \mathrm{M}\right)$, whereas in SBCE2 melanoma cells the effect was not seen at concentrations $<10^{-6} \mathrm{M}$ (data not shown).

Expression of quinone oxidoreductase and nuclear melatonin receptor. The quinone oxidoreductase type 1 (NQO1) was expressed in all tested melanoma cell lines (Fig. 3A), and NQO2 was expressed in three of the cell lines with decreasing level of expression (WM-164 > WM-98 > SCBE2) (Fig. 3B). NQO2 mRNA in SKMEL-188 was below the level of detectability. RT-PCR for the nuclear receptor ROR $\alpha / R Z R \alpha$ and the ROR $\alpha 1$, ROR $\alpha 2$, ROR $\alpha 3$ and ROR $\alpha 4$ (RZR $\alpha)$ splicing variants is presented in Fig. 4. The 320-bp cDNA fragment of ROR $\alpha$ was detected in three melanoma cell lines, but not in SKMEL-188 (Fig. 4A). Subspecification of receptor isoforms 
A

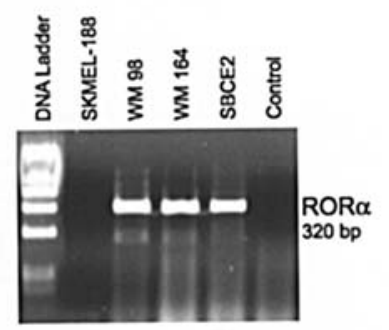

B

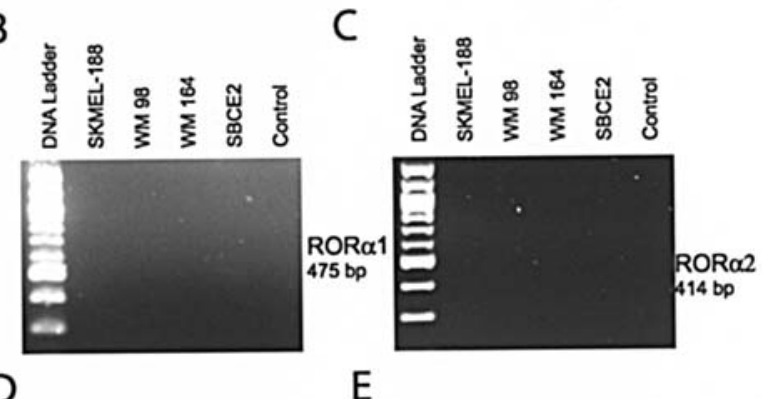

D

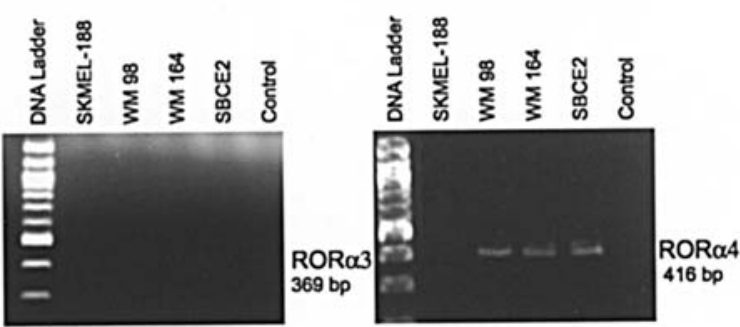

Figure 4. Expression of alternatively spliced nuclear receptors ROR $\alpha$. The common fragment $(\mathrm{ROR} \alpha)$ and the isoform ROR $\alpha 4$ were detected in WM-164, WM-98 and SBCE2 melanoma cell lines, whereas SKMEL-188 did not express the nuclear receptor. Universal primers were used to detect ROR $\alpha$ mRNA (A) as described in Materials and methods. Primers for expression of ROR $\alpha$ isoforms ROR $\alpha 1$ (B), ROR $\alpha 2$ (C), ROR $\alpha 3$ (D) and ROR $\alpha 4(\mathrm{RZR} \alpha)$ (E) were studied with a set of primers as published (59). DNA marker was 100-bp ladder except for A, for which GeneRuler 100-bp DNA ladder was used. The last line in each panel represents the negative control without cDNA.

showed ROR $\alpha 4(\mathrm{RZR} \alpha)$ in WM-98, WM-164 and SCBE2 (Fig. 4E), whereas ROR $\alpha 1$, ROR $\alpha 2$ and ROR $\alpha 3$ were not present in any of the cell lines (Fig. 4B-D). A summary of these results is presented in Table IV.

\section{Discussion}

The present study shows distinct oncostatic effects of melatonin at different concentrations in four clinically representative melanoma cell lines under a variety of conditions that included cultivation period ( $12 \mathrm{~h}$ and 14 days), cell line specificity and cell cycle synchronization (free running vs. synchronized). Additionally, the gene expression of quinone oxidoreductase 1 and 2 as well as nuclear receptor $\operatorname{ROR} \alpha$ and its splicing variants was investigated.

Three cell lines (WM-164, WM-98, SBCE2) were strongly inhibited in their growth by melatonin, whereas SKMEL-188 melanoma cells showed lower suppression. The strongest inhibition by melatonin was observed in melanoma cells that derived from radial growth (SBCE2), putatively representative for the behaviour of early-stage tumor growth. Melanoma cells of vertical growth phase and metastatic tumor origin demonstrated a smaller responsiveness to melatonin.

Differences of growth suppression were also observed in dependency of culture conditions. In SKMEL-188, WM-164 and SBCE2 melanoma cells, the growth suppressing effect of melatonin was stronger when cells had been cultivated in serum-free (synchronized) conditions. Serum-free cultivation leads the cells into a starvation state in which proliferation rate and metabolism are reduced followed by cell cycle synchronization. A stronger suppressive effect of melatonin on cell proliferation in slower growing melanoma cells from earlier passages had been previously noted and ascribed to a loss of receptors regulating the tumor suppressive effect of melatonin (51).

For the clonogenic growth assay, we selected two cell lines exhibiting different responses to melatonin in the thymidineassay, e.g. SKMEL-188 showing the lowest suppressive effect by melatonin at $10^{-3} \mathrm{M}$, but the highest sensitivity responding to the concentration of $10^{-10}-10^{-12} \mathrm{M}$. In contrast, SBCE2 showed the strongest suppression by melatonin $\left(10^{-3} \mathrm{M}\right)$, but low sensitivity (no effect at concentrations $>10^{-7} \mathrm{M}$ ). The clonogenic growth assay confirmed the results obtained in proliferation assessment with $\left[{ }^{3} \mathrm{H}\right]$-thymidine incorporation. Thus, SKMEL-188 showed lesser inhibitory melatonin effects than SBCE2. Moreover, the sensitivity to melatonin treatment in colony growth increased in SBCE2 melanoma cells, since over a cultivation period of 14 days, the suppression by

Table IV. Expression profile of nuclear receptor ROR $\alpha$ and its four isoforms ROR $\alpha 1$, ROR $\alpha 2$, ROR $\alpha 3$ and ROR $\alpha 4$ and NQO1 and 2 in melanoma lines.

\begin{tabular}{|c|c|c|c|c|c|c|c|c|c|}
\hline \multirow[b]{2}{*}{ Cell line } & \multirow{2}{*}{$\begin{array}{c}\text { Nuclear } \\
\text { receptor } \\
\text { ROR } \alpha\end{array}$} & \multicolumn{4}{|c|}{ Nuclear receptor splicing variants } & \multicolumn{2}{|c|}{ Quinone reductases } & \multicolumn{2}{|c|}{ Housekeeping genes } \\
\hline & & $\mathrm{ROR} \alpha 1$ & $\mathrm{ROR} \alpha 2$ & $\mathrm{ROR} \alpha 3$ & $\begin{array}{l}\mathrm{ROR} \alpha 4 \\
(\mathrm{RZR} \alpha)\end{array}$ & NQO1 & NQO2 & GAPDH & $18 \mathrm{~S}$ \\
\hline SKMEL-188 & - & - & - & - & - & + & - & + & + \\
\hline WM 164 & + & - & - & - & + & + & +++ & + & + \\
\hline WM 98 & + & - & - & - & + & + & ++ & + & + \\
\hline SBCE2 & + & - & - & - & + & + & + & + & + \\
\hline
\end{tabular}


melatonin $\left(10^{-3} \mathrm{M}\right)$ was stronger, to $3 \%$ of control as compared to $20 \%$ of controls in the $\left[{ }^{3} \mathrm{H}\right]$-thymidine incorporation assay. In fact, in both cell lines the effective concentration range on colony growth was comparable with that observed in the $\left[{ }^{3} \mathrm{H}\right]$-thymidine incorporation experiments.

The effective concentrations of melatonin (inducing statistically significant suppression) were in the range of $10^{-3}$ to $10^{-7}$ for WM-164 and SBCE2 melanoma cell lines and $10^{-3}$ and $10^{-4}$ in WM-98. Studies with murine melanoma cells showed proliferation suppressive effects of melatonin at similar concentrations from $10^{-3}$ to $10^{-6} \mathrm{M}(46)$, and in the human malignant melanoma cell line M6, melatonin effective suppression of forskolin-stimulated cAMP accumulation as a sign for decreased proliferation occurred at $10^{-4}-10^{-9} \mathrm{M}(62)$. A decreased growth rate has been noted in SKMEL-28 human melanoma cells at the minimal effective concentration of $10^{-8} \mathrm{M}(63)$. To the authors knowledge, effective suppression of melanoma cell proliferation by melatonin at concentrations below $10^{-8} \mathrm{M}$ has so far been noted only in rodent melanomas and human uveal melanoma cell lines $\left(10^{-8}-10^{-10} \mathrm{M}\right)(32,64,65)$ and in PG19 and B16BL6 mouse melanoma $\left(10^{-9}-10^{-11} \mathrm{M}\right)$ (66). Interestingly, the present study has also shown melatonin effectiveness at concentrations as low as $10^{-12} \mathrm{M}$ in the SKMEL-188 human melanoma cell line. Also of interest is the slight stimulation of growth in two cell lines (WM-164 and SBCE2) at the melatonin concentration of $10^{-9} \mathrm{M}$, since at the same concentration, a stimulation of $15 \%$ was reported in B16 melanoma cells (67).

The expression pattern of membrane and nuclear receptors for melatonin has been found to differentially modify melatonin effects in malignant cells of different origin. For example, studies in the colon 38 carcinoma cell line identified both the nuclear receptor RZR/ROR $(\operatorname{ROR} \alpha)$ and the cell membrane receptor MT2, but not MT1, as being responsible for the oncostatic effect of melatonin $(41,52,68,69)$. In contrast, the MT1 receptor was responsible for the enhancement of the tumor suppressing effect of melatonin in MCF-7 breast cancer cells $(39,53)$ and in S-91 murine melanoma cells $(45)$. In uveal melanoma cell lines, melatonin and agonists for MT1 and MT2 inhibited melanoma growth, whereas the nuclear receptor was not involved in growth suppression (47). In estrogen-receptor positive breast cancer cells, the expression of ROR $\alpha$ was found to clearly contribute to melatonin-induced growth inhibition (70). These observations suggest that the differential expression of membrane and nuclear receptors defines a specific celltype related phenotype, which may be the main determinant of specific responses to melatonin.

The strongest proliferation suppression in the present study was found in the melanoma cell lines WM-164, WM-98 and SBCE2 that express the nuclear receptor ROR $\alpha$ and its specific isoform ROR $\alpha 4$. These results cannot be compared with the literature since to the authors' knowledge, this is the first report on $\mathrm{ROR} \alpha$ nuclear receptor and its four splicing variants $\mathrm{ROR} \alpha 1, \mathrm{ROR} \alpha 2, \mathrm{ROR} \alpha 3$ and $\mathrm{ROR} \alpha 4$ in human malignant melanoma cell lines. Expression of ROR $\alpha$ nuclear receptor, however, was previously demonstrated in skin cells [including normal and immortalized melanocytes and keratinocytes and dermal fibroblasts (18)] and in hair follicles (28). Whether the present observation of differential melatonin receptor expression in malignant cells has a causal correlation with melatonin responsiveness, will be a subject of further testing with nuclear receptor antagonists and/or $\mathrm{ROR} \alpha^{-/-}$ receptor cell lines. The strong proliferation suppression induced by high concentrations of melatonin in ROR $\alpha$ positive melanoma cells may be explained by intracellular diffusion into the nuclear compartment with building high melatonin intranuclear levels that effectively bind the nuclear receptor. Thus, it can be speculated that activation of nuclear receptor $\mathrm{ROR} \alpha$ executes a proapoptotic program, which leads to cell death in the majority of the cell population. Interestingly, lines expressing nuclear receptors showed stronger growth inhibition. In addition, expression of membrane receptor MT2 as observed in SKMEL-188 melanoma cells in previous studies (24) seems to contribute to the high sensitivity of this cell line to inhibition by melatonin at low concentrations $\left(10^{-12}\right.$. $\left.10^{-10} \mathrm{M}\right)$, but also to the small magnitude of the suppressing effect.

The enzymes NAD(P)H:quinone oxidoreductase 1 (NQO1, QR1) and the NRH:quinone oxidoreductase 2 (NQO2, QR2), which is identical with the melatonin binding site MT3 $(71,72)$, have been previously detected in normal and immortalized melanocytes and keratinocytes as well as in adult dermal fibroblasts (18). In the present study we extended this investigation to melanoma cell lines. Whereas NQO1 was expressed in all tested cell lines, NQO2 expression was limited to WM164, WM-98 and SBCE2 cell lines. NQO1 is ubiquitously expressed in physiological and pathological conditions. In malignant conditions, Vella et al found NQO1 in solid tumors of liver, thyroid, adrenal, breast, colon, and non-small cell lung cancers (58). In contrast, NQO2 expression is quite variable and dependent, among others, on the species tested. High gene expression, for example, is detected in the skeletal muscle of humans, but not in mouse muscle (58). NQO2 was also found in relatively high levels in normal human liver, while expression of NQO1 was very low, but reverse expression was found in malignant tissues (73). Even though to date the biological role of NQO2 is poorly understood, there are studies showing evidence for its involvement in skin carcinogenesis. The most prominent example is that NQO2 knockout mice are far more prone to develop skin tumors after the topical application of carcinogens (74). More recently, inhibition of melanoma cell growth and clonogenicity was correlated with upregulation of NQO2 and p53 (75). In this context, the parallel inhibition of cell growth induced by melatonin, the natural ligand of NQO2, suggests that expression of NQO2 might be another factor determining the oncostatic effects of melatonin.

In conclusion, there may be dynamic correlations between melatonin receptor expression and its oncostatic effects. Since there is also heterogenity across different melanoma cell lines, more work is needed to fully characterize the factors determining dependency of dynamic fluctuation over time and tumor behavior. Clarification of this area will allow extension of our results to the clinically encountered forms of malignant melanoma. Moreover, as a concept for optimizing anticarcinogenic treatment with melatonin, future in vitro and in vivo studies may use combinations of selective agonists for ROR $\alpha$, MT2 receptor and the cytosolic NQO2 melatonin binding site to increase sensitivity and response to treatment. 


\section{Acknowledgements}

We thank Dr Mark A. Miller, Department of Molecular Sciences, UTHSC, for his support. This work was supported by 'German Academy of Natural Scientists Leopoldina' with funds from the 'Federal Ministry of Education and Research' (ref. no. BMBF-LPD 9901/8-113) to TWF, a University of Tennessee Cancer Center Pilot Grant to A.S., T.W.F. and T.W.S. The generous support of ASATONA AG, Switzerland, is also acknowledged.

\section{References}

1. Arendt J: Melatonin. Clin Endocrinol 29: 205-229, 1988.

2. Lerner AB, Case JD and Takahashi Y: Isolation of melatonin, a pineal factor that lightens melanocytes. J Am Chem Soc 80: 2587,1958

3. Tan DX, Chen LD, Poeggeler B, Manchester LC and Reiter RJ: Melatonin: a potent, endogenous hydroxyl radical scavenger. Endocr J 1: 57-60, 1993

4. Tan DX, Manchester LC, Hardeland R, et al: Melatonin: a hormone, a tissue factor, an autocoid, a paracoid, and an antioxidant vitamin. J Pineal Res 34: 75-78, 2003.

5. Tan DX, Reiter RJ, Manchester LC, et al: Chemical and physical properties and potential mechanisms: melatonin as a broad spectrum antioxidant and free radical scavenger. Curr Top Med Chem 2: 181-197, 2002.

6. Maestroni GJ: The immunotherapeutic potential of melatonin. Expert Opin Investig Drugs 10: 467-476, 2001.

7. Reiter RJ, Tan DX, Poeggeler B, Menendez-Pelaez A, Chen LD and Saarela S: Melatonin as a free radical scavenger: implications for aging and age-related diseases. Ann NY Acad Sci 719: 1-12, 1994.

8. Karasek M and Reiter RJ: Melatonin and aging. Neuroendocrinol Lett 23 (suppl 1): 14-16, 2002

9. Karbownik M: Potential anticarcinogenic action of melatonin and other antioxidants mediated by antioxidative mechanisms. Neuroendocrinol Lett 23 (suppl 1): 39-44, 2002.

10. Reiter RJ, Tan DX and Maldonado MD: Melatonin as an antioxidant: physiology versus pharmacology. J Pineal Res 39: 215-216, 2005

11. Bubenik GA: Gastrointestinal melatonin: localization, function, and clinical relevance. Dig Dis Sci 47: 2336-2348, 2002.

12. Bubenik GA, Pang SF, Cockshut JR, et al: Circadian variation of portal, arterial and venous blood levels of melatonin in pigs and its relationship to food intake and sleep. J Pineal Res 28: 9-15, 2000

13. Carrillo-Vico A, Calvo JR, Abreu P, et al: Evidence of melatonin synthesis by human lymphocytes and its physiological significance: possible role as intracrine, autocrine, and/or paracrine substance. FASEB J 18: 537-539, 2004.

14. Cahill GM and Besharse JC: Light-sensitive melatonin synthesis by Xenopus photoreceptors after destruction of the inner retina Vis Neurosci 8: 487-490, 1992.

15. Conti A, Conconi S, Hertens E, Skwarlo-Sonta K, Markowska M and Maestroni JM: Evidence for melatonin synthesis in mouse and human bone marrow cells. J Pineal Res 28: 193-202, 2000.

16. Tan DX, Manchester LC, Reiter RJ, et al: Identification of highly elevated levels of melatonin in bone marrow: its origin and significance. Biochim Biophys Acta 1472: 206-214, 1999.

17. Slominski A: Neuroendocrine system of the skin. Dermatology 259: 199-208, 2005.

18. Slominski A, Fischer TW, Zmijewski MA, et al: On the role of melatonin in skin physiology and pathology. Endocrine 27: 137-148, 2005

19. Slominski A, Pisarchik A, Semak I, et al: Serotoninergic and melatoninergic systems are fully expressed in human skin. FASEB J 16: 896-898, 2002.

20. Slominski A, Wortsman J and Tobin DJ: The cutaneous serotoninergic/melatoninergic system: securing a place under the sun. FASEB J 19: 176-194, 2005.

21. Slominski A and Wortsman J: Neuroendocrinology of the skin. Endocrine Rev 21: 457-487, 2000.

22. Fischer TW, Zbytek B, Sayre RM, et al: Melatonin increases survival of HaCaT keratinocytes by suppressing UV-induced apoptosis. J Pineal Res 40: 18-26, 2006.
23. Fischer TW, Sweatman TW, Semak I, Sayre RM, Wortsman J and Slominski A: Constitutive and UV-induced metabolism of melatonin in keratinocytes and cell-free systems. FASEB J (In press).

24. Slominski A, Pisarchik A, Zbytek B, Tobin DJ, Kauser S and Wortsman J: Functional activity of serotoninergic and melatoninergic systems expressed in the skin. J Cell Physiol 196: $144-153,2003$.

25. Hipler UC, Fischer TW and Elsner P: HaCaT cell proliferation influenced by melatonin. Skin Pharmacol Appl Skin Physiol 16: 379-385, 2003.

26. Slominski A, Chassalerris N, Mazurkiewicz J and Paus R: Murine skin as a target for melatonin bioregulation. Exp Dermatol 3: $45-50,1994$

27. Fischer TW, Fischer A, Knöll B, Hipler UC and Elsner P: Melatonin in low doses enhances in vitro human hair follicle proliferation and inhibits hair growth in high doses. Arch Dermatol Res 292: 147, 2000.

28. Kobayashi H and Paus R: Expression and functional relevance of melatonin receptors in hair follicle biology. Exp Dermatol 14: 157,2005

29. Fischer TW, Burmeister G, Schmidt HW and Elsner P: Melatonin increases anagen hair rate in women with androgenetic alopecia or diffuse alopecia: results of a pilot randomized controlled trial. Br J Dermatol 150: 341-345, 2004.

30. Slominski A, Wortsman J, Plonka PM, Schallreuter KU, Paus R and Tobin DJ: Hair follicle pigmentation. J Invest Dermatol 124: 13-21, 2005.

31. Slominski A and Paus R: Melanogenesis is coupled to murine anagen: toward new concepts for the role of melanocytes and the regulation of melanogenesis in hair growth. J Invest Dermatol 101: S90-S97, 1993.

32. Slominski A and Pruski D: Melatonin inhibits proliferation and melanogenesis in rodent melanoma cells. Exp Cell Res 206: 189-194, 1993.

33. Slominski A, Tobin DJ, Shibahara S and Wortsman J: Melanin pigmentation in mammalian skin and its hormonal regulation. Physiol Rev 84: 1155-1228, 2004.

34. Fischer TW and Elsner P: The antioxidative potential of melatonin in the skin. Curr Probl Dermatol 29: 165-174, 2001

35. Fischer TW, Scholz G, Knoll B, Hipler UC and Elsner P: Melatonin suppresses reactive oxygen species in UV-irradiated leukocytes more than vitamin $\mathrm{C}$ and trolox. Skin Pharmacol Appl Skin Physiol 15: 367-373, 2002.

36. Fischer TW, Scholz G, Knoll B, Hipler UC and Elsner P: Melatonin suppresses reactive oxygen species induced by UV irradiation in leukocytes. J Pineal Res 37: 107-112, 2004.

37. Bangha E, Elsner P and Kistler GS: Suppression of UV-induced erythema by topical treatment with melatonin (N-acetyl-5methoxytryptamine). Influence of the application time point. Dermatology 195: 248-252, 1997.

38. Dreher F, Gabard B, Schwindt DA and Maibach HI: Topical melatonin in combination with vitamins $\mathrm{E}$ and $\mathrm{C}$ protects skin from ultraviolet-induced erythema: a human study in vivo. Br J Dermatol 139: 332-339, 1998.

39. Dillon DC, Easley SE, Asch BB, et al: Differential expression of high-affinity melatonin receptors (MT1) in normal and malignant human breast tissue. Am J Clin Pathol 118: 451-458, 2002.

40. Moretti RM, Montagnani Marelli M, Sala A, Motta M and Limonta P: Activation of the orphan nuclear receptor RORalpha counteracts the proliferative effect of fatty acids on prostate cancer cells: crucial role of 5-lipoxygenase. Int J Cancer 112: 87-93, 2004

41. Karasek M, Carrillo-Vico A, Guerrero JM, Winczyk K and Pawlikowski M: Expression of melatonin MT(1) and MT(2) receptors, and ROR alpha(1) receptor in transplantable murine Colon 38 cancer. Neuroendocrinol Lett 23 (suppl 1): 55-60, 2002.

42. Carlson JA, Ross JS, Slominski A, et al: Molecular diagnostics in melanoma. J Am Acad Dermatol 52: 743-775; quiz 775-778, 2005.

43. Slominski A, Wortsman J, Carlson A, Matsuoka L, Balch CM and Mihm M: Malignant melanoma: an update. Arch Pathol Lab Med 125: 1295-1306, 2001

44. Linette GP, Carlson JA, Slominski A, Mihm MC and Ross JS Biomarkers in melanoma: stage III and IV disease. Expert Rev Mol Diagn 5: 65-74, 2005.

45. Kadekaro AL, Andrade LNS, Floeter-Winter LM, et al: MT-1 melatonin receptor expression increases the antiproliferative effect of melatonin on S-91 murine melanoma cells. J Pineal Res 36: 204-211, 2004. 
46. Yerneni LK and Jayaraman S: Pharmacological action of high doses of melatonin on B16 murine melanoma cells depends on cell number at time of exposure. Melanoma Res 13: 113-117, 2003.

47. Roberts JE, Wiechmann AF and Hu DN: Melatonin receptors in human uveal melanocytes and melanoma cells. J Pineal Res 28: 165-171, 2000.

48. Bartsch C, Bartsch $\mathrm{H}$ and Karasek M: Melatonin in clinical oncology. Neuroendocrinol Lett 23 (suppl 1): 30-38, 2002.

49. Lissoni P, Vaghi M, Ardizzoia A, et al: A phase II study of chemoneuroimmunotherapy with platinum, subcutaneous lowdose interleukin-2 and the pineal neurohormone melatonin (P.I.M.) as a second-line therapy in metastatic melanoma patients progressing on dacarbazine plus interferon-alpha. In Vivo 16: 93-96, 2002.

50. Mills E, Wu P, Seely D and Guyatt G: Melatonin in the treatment of cancer: a systematic review of randomized controlled trials and meta-analysis. J Pineal Res 39: 360-366, 2005.

51. Bartsch H, Bartsch C and Fleming B: Differential effect of melatonin on slow and fast growing passages of a human melanoma cell line. Neuro Endocrinol Lett 8: 289-293, 1986.

52. Winczyk K, Pawlikowski M, Lawnicka H, et al: Effects of melatonin and melatonin receptors ligand $\mathrm{N}-[(4-$ methoxy- $1 \mathrm{H}-$ indol-2-yl)methyl]propanamide on murine Colon 38 cancer growth in vitro and in vivo. Neuro Endocrinol Lett 23 (suppl 1): 50-54, 2002.

53. Yuan L, Collins AR, Dai J, Dubocovich ML and Hill SM: MT(1) melatonin receptor overexpression enhances the growth suppressive effect of melatonin in human breast cancer cells. Mol Cell Endocrinol 192: 147-156, 2002.

54. Brydon L, Roka F, Petit L, et al: Dual signaling of human Mel1a melatonin receptors via $\mathrm{G}(\mathrm{i} 2), \mathrm{G}(\mathrm{i} 3)$, and $\mathrm{G}(\mathrm{q} / 11)$ proteins. Mol Endocrinol 13: 2025-2038, 1999.

55. Chan AS, Lai FP, Lo RK, Voyno-Yasenetskaya TA, Stanbridge EJ and Wong YH: Melatonin mt1 and MT2 receptors stimulate c-Jun $\mathrm{N}$-terminal kinase via pertussis toxin-sensitive and -insensitive G proteins. Cell Signal 14: 249-257, 2002.

56. Ho MK, Yung LY, Chan JS, Chan JH, Wong CS and Wong YH: Galpha(14) links a variety of G(i)- and G(s)-coupled receptors to the stimulation of phospholipase C. Br J Pharmacol 132: 1431-1440, 2001

57. Mailliet F, Ferry G, Vella F, Thiam K, Delagrange P and Boutin JA: Organs from mice deleted for NRH:quinone oxidoreductase 2 are deprived of the melatonin binding site MT3. FEBS Lett 578: 116-120, 2004.

58. Vella F, Ferry G, Delagrange P and Boutin JA: NRH:quinone reductase 2: an enzyme of surprises and mysteries. Biochem Pharmacol 71: 1-12, 2005

59. Pozo D, Garcia-Maurino S, Guerrero JM and Calvo JR: mRNA expression of nuclear receptor RZR/RORalpha, melatonin membrane receptor MT, and hydroxindole-O-methyltransferase in different populations of human immune cells. J Pineal Res 37: 48-54, 2004.

60. Slominski A, Ermak G and Wortsman J: Modification of melanogenesis in cultured human melanoma cells. In Vitro Cell Dev Biol 35: 564-565, 1999.
61. Slominski A, Wortsman J, Kohn L, et al: Expression of hypothalamic-pituitary-thyroid axis related genes in the human skin. J Invest Dermatol 119: 1449-1455, 2002.

62. Ying SW, Niles LP and Crocker C: Human malignant melanoma cells express high-affinity receptors for melatonin: antiproliferative effects of melatonin and 6-chloromelatonin. Eur J Pharmacol 246: 89-96, 1993.

63. Souza AV, Visconti MA and Castrucci AM: Melatonin biological activity and binding sites in human melanoma cells. J Pineal Res 34: 242-248, 2003.

64. Hu DN and Roberts JE: Melatonin inhibits growth of cultured human uveal melanoma cells. Melanoma Res 7: 27-31, 1997.

65. Hu DN, McCormick SA and Roberts JE: Effects of melatonin, its precursors and derivatives on the growth of cultured human uveal melanoma cells. Melanoma Res 8: 205-210, 1998.

66. Cos S, Garcia-Bolado A and Sanchez-Barcelo EJ: Direct antiproliferative effects of melatonin on two metastatic cell sublines of mouse melanoma (B16BL6 and PG19). Melanoma Res 11: 197-201, 2001.

67. Helton RA, Harrison WA, Kelley K and Kane MA: Melatonin interactions with cultured murine B16 melanoma cells. Melanoma Res 3: 403-413, 1993

68. Winczyk K, Pawlikowski M and Karasek M: Melatonin and RZR/ROR receptor ligand CGP 52608 induce apoptosis in the murine colonic cancer. J Pineal Res 31: 179-182, 2001.

69. Winczyk K, Pawlikowski M, Guerrero JM and Karasek M: Possible involvement of the nuclear RZR/ROR-alpha receptor in the antitumor action of melatonin on murine Colon 38 cancer. Tumour Biol 23: 298-302, 2002.

70. Girgert R, Bartsch C, Hill SM, Kreienberg R and Hanf V: Tracking the elusive antiestrogenic effect of melatonin: a new methodological approach. Neuro Endocrinol Lett 24: 440-444, 2003.

71. Nosjean O, Ferro M, Coge F, et al: Identification of the melatonin-binding site MT3 as the quinone reductase 2. J Biol Chem 275: 31311-31317, 2000.

72. Mailliet F, Ferry G, Vella F, et al: Characterization of the melatoninergic MT(3) binding site on the NRH:quinone oxidoreductase 2 enzyme. Biochem Pharmacol 71: 74-88, 2005.

73. Strassburg A, Strassburg CP, Manns MP and Tukey RH: Differential gene expression of NAD $(\mathrm{P}) \mathrm{H}$ :quinone oxidoreductase and NRH:quinone oxidoreductase in human hepatocellular and biliary tissue. Mol Pharmacol 61: 320-325, 2002.

74. Iskander K, Paquet M, Brayton C and Jaiswal AK: Deficiency of NRH:quinone oxidoreductase 2 increases susceptibility to 7,12-dimethylbenz(a)anthracene and benzo(a)pyrene-induced skin carcinogenesis. Cancer Res 64: 5925-5928, 2004.

75. Hsieh TC, Wang Z, Hamby CV and Wu JM: Inhibition of melanoma cell proliferation by resveratrol is correlated with upregulation of quinone reductase 2 and p53. Biochem Biophys Res Commun 334: 223-230, 2005.

76. Naji L, Carrillo-Vico A, Guerrero JM and Calvo JR: Expression of membrane and nuclear melatonin receptors in mouse peripheral organs. Life Sci 74: 2227-2236, 2004. 